\title{
Effect of Crude Extracts of Edible Mushroom Species of Agaricus bisporus and Auricularia auricula on Growth Performance of Broiler Chickens
}

\author{
Reynaldy H. Ardyansyah ${ }^{1 *}$, Danung Nur Adli ${ }^{1}$, M. Halim Natsir ${ }^{2}$, and Osfar Sjofjan ${ }^{2}$ \\ ${ }^{1}$ Postgraduate Student of Animal Feed Science and Technology Department, Faculty of Animal Science, Brawijaya University, 65145 Malang, Indonesia \\ ${ }^{2}$ Lecturer of Animal Feed Science and Technology Department, Faculty of Animal Science, Brawijaya University, 65145 Malang, Indonesia \\ *Corresponding author's Email: reynaldyhadia@gmail.com; ORCID: 0000-0003-3003-7974
}

Received: 23 Jul. 2020

Accepted: 02 Sept. 2020

\begin{abstract}
The current study aimed to evaluate the effect of Agaricus bisporus and Auricularia auricula crude extracts as feed additives on the growth performance of broiler chickens. The samples included 240 one-day-old chicks randomly divided into 8 dietary treatments, each treatment consisted of 3 replicates with 10 chicks per replicate. The dietary treatment groups were control group (T0), basal diet + zinc bacitracin (T1), basal diets $+0.4 \%$ Agaricus bisporus extract (T2), basal diet $+0.8 \%$ Agaricus bisporus extract (T3), basal diet $+1.2 \%$ Agaricus bisporus extract (T4), basal diet $+0.4 \%$ Auricularia auricula extract (T5), basal diet $+0.8 \%$ Auricularia auricula extract (T6), and basal diet $+1.2 \%$ Auricularia auricula extract (T7). The measured variables included feed intake, body weight gain, feed conversion ratio, and production index. In addition, the study aimed to evaluate the reducing sugars level, antioxidant $\mathrm{IC}_{50}$, and antimicrobial efficacy of mushroom extracts prepared using three different solvents (i.e., water, ethanol, and methanol). The findings indicated that methanolic extract contained higher reducing sugars and had better antimicrobial efficacy. The results of experimental research revealed that mushrooms crude extracts had no significant effects on the growth performance of broiler chickens.
\end{abstract}

Keywords: Antibiotic, Broiler performance, Extract, Mushroom

\section{INTRODUCTION}

Zinc bacitracin is one of the antibiotic growth promoters (AGP) that is usually used in the poultry industry (Sarmah et al., 2006). The AGP residues in animal products, such as meat or eggs, have negative effects on human health and immunity mainly due to the development of bacterial resistance. Therefore, it is of utmost importance to seek alternatives to AGP (Suresh et al., 2017).

Agaricus bisporus and Auricularia auricular are two types of mushroom species cultivated in the subtropical climate, such as Indonesia. They contain different polysaccharide compounds, including $\beta$-glucan, which has a significant pharmacological effect on activating innate immunity by macrophage cell activation (Minato and Abe, 2013). Chae et al. (2006) reported that broilers fed with $\beta$ glucan at $0.04 \%$ level had a significant increase in CD8+ cells at 42 days of age and a relative increase in CD4+ cells.

Lee and Kim (2005) reported that Auricularia auricular contains $8.86 \%$ glucan, out of which $0.31 \%$ is $\alpha$ - glucan and $8.55 \%$ is $\beta$-glucan. On the other hand, Agaricus bisporus is made of $7.19 \%$ glucan, including $0.60 \% \alpha$-glucan and $6.59 \% \beta$-glucan. Zeng et al. (2012) reported that Auricularia auricula extract contains a heteropolysaccharide composed of various monosaccharides, such as galactose, mannose, glucose, arabinose, and rhamnose. Agaricus bisporus extracted and semi-purified using hot water and $65 \%$ ethanol showed a higher polysaccharide content of up to $74.4 \%$, encompassing $63.8 \%$ glucan content, $5.6 \% \alpha$-glucan and $58.2 \%$ in $\beta$-glucan (Kozarski et al., 2011).

Sulfated polysaccharides of Auricularia auricula extracted using $95 \%$ ethanol could enhance the immunity of white roman chickens (Nguyen et al., 2012). Another study demonstrated that extract from shiitake mushroom increased the total population of Bifidobacteria from 7.47 to $8.67 \log ^{10} \mathrm{CFU}$ and reduced Salmonella counts from 5.98 to $5.81 \log ^{10} \mathrm{CFU}$ (Willis et al., 2009). Bifidobacteria are known to improve animal production, gut morphology, and health. Another study conducted by Willis et al. 
(2013) indicated that 5\% oyster mushroom supplementation in broiler diets resulted in higher body weight than other mushroom types. The supplementation of Agaricus bisporus mushroom in turkey diets significantly increased body weight and weight gain. Moreover, it reduced feed conversion ratio (FCR) but had an insignificant effect on feed intake (Giannenas et al., 2011). With this background in mind, the present study aimed to evaluate the effects of Agaricus bisporus and Auricularia auricular crude extracts prepared using microwave-assisted extractor (MAE) on broiler performance.

\section{MATERIALS AND METHODS}

\section{Ethical approval}

The in vivo trials were approved by the Animal Care and Use Committee of Brawijaya University (certificate number: 065-KEP-UB-2020).

\section{Mushroom preparation and extraction}

Agaricus bisporus and Auricularia auricula were purchased from a local mushroom farmer in the Singosari sub-district, Malang District, East Java, Indonesia. The mushrooms were segmented into the fragments of 0.2-0.3 $\mathrm{cm}$ in size, then $100 \mathrm{~g}$ of each mushroom was added into a $500 \mathrm{~mL}$ flask and mixed and soaked with different solvents $(200 \mathrm{~mL}$ of distilled water, ethanol $96 \%$, and methanol $70 \%$ ) for $24 \mathrm{~h}$. In the next step, the solvents were evaporated using modified microwave heating as described by Purwanto et al. (2010). The modified MAE was used during the experiment at $50{ }^{\circ} \mathrm{C}$ for 15 minutes.

\section{Determination of reducing sugars, antioxidant $\mathrm{IC}_{50}$, and antimicrobial efficacy of mushrooms (Experiment 1)}

The disk diffusion method was performed to investigate the antimicrobial activity of Agaricus bisporus and Auricularia auricula crude extracts using nutrient agar medium (Merck KGaA, 64271 Darmstadt, Germany). The bacteria (Salmonella Typhimurium, Escherichia coli, and Lactobacillus aureus) were provided and cultured in nutrient agar at $37{ }^{\circ} \mathrm{C}$ for 24 hours at the Department of Plant Pest and Diseases, Brawijaya University. Afterward, Agaricus bisporus and Auricularia auricula crude extracts (in 50\% concentration) were placed in the cylinders. Finally, the plates were incubated at $37{ }^{\circ} \mathrm{C}$ for 24 hours, then the diameter of the inhibition zone was measured using calipers.
Lane-Eynon method was performed to determine the concentration of reducing sugar of Agaricus bisporus and Auricularia auricula crude extracts (Afriza and Ismanilda, 2019). Approximately $5 \mathrm{~g}$ mushroom crude extract was added to $25 \mathrm{~mL}$ of distilled water and $1 \mathrm{~mL}$ of $\mathrm{HCl} 37 \%$. The sample was then heated for $15 \mathrm{~min}$ at $80^{\circ} \mathrm{C}$. Following that $\mathrm{Na}_{2} \mathrm{CO}_{3} 10 \%$ was added until greenish, and total volume was made to $125 \mathrm{ml}$ by adding distilled water, then the final solution was stirred, and filtered. The filtrate was immediately transferred into the burette. Furthermore, $5 \mathrm{~mL}$ of Fehling A and Fehling B were mixed at the ratio of 50:50. The mixture of Fehling A and Fehling B was then added to $7.5 \mathrm{~mL}$ of the solution and the solution was boiled later. The color indicator was used by adding $75 \mu \mathrm{L}$ of methylene blue. Finally, the solution was titrated until the blue color disappeared. The reducing sugars was calculated as follows:

Reducing sugar $=\frac{\text { Dilution volume }}{\text { Titrated volume }} \times \frac{100}{\text { Sample weight }} \times 0.001$

The antioxidant activity was performed according to (Osawa and Namiki, 1981). Briefly, $20 \mathrm{mg} / \mathrm{mL}$ of mushroom crude extract was dissolved in $4 \mathrm{~mL}$ of $95 \%$ $(\mathrm{w} / \mathrm{v})$ ethanol and mixed with linoleic acid $(2.51 \%, \mathrm{v} / \mathrm{v})$ in 99.5\% (w/v) ethanol $(4.1 \mathrm{~mL}), 0.05 \mathrm{M}$ phosphate buffer pH $7.0(8 \mathrm{~mL})$, and distilled water $(3.9 \mathrm{~mL})$ and kept in screwcap containers at $40{ }^{\circ} \mathrm{C}$ in the dark. Then, $0.1 \mathrm{~mL}$ of this solution was then added to $9.7 \mathrm{~mL}$ of $75 \%(\mathrm{v} / \mathrm{v})$ ethanol and $0.1 \mathrm{~mL}$ of $30 \%(\mathrm{w} / \mathrm{v})$ ammonium thiocyanate. Precisely 3 min after the addition of $0.1 \mathrm{~mL}$ of $20 \mathrm{mM}$ ferrous chloride in $3.5 \%(\mathrm{v} / \mathrm{v})$ hydrochloric acid to the reaction mixture, the absorbance at $500 \mathrm{~nm}$ of the resulting red solution was measured, and it was measured again every $24 \mathrm{~h}$ until the absorbance of the control reached the maximum value. The percentage inhibition of linoleic acid peroxidation was calculated as follows:

Inhibition $(\%)=100-[($ absorbance increases of the sample/absorbance increases of the control $) \times 100]$.

Effect of mushroom-supplemented diet on broiler growth performance (Experiment 2)

In this experiment, methanol was used as a solvent to extract the mushroom samples. To conduct the study, 240 one-day-old chicks (unsexed, average body weight of 37.6 $\pm 2.90 \mathrm{~g} /$ chick), strain Lohman Grade Platinum, were purchased from Multibreeder Adirama Company in Indonesia. The samples were randomly divided into eight dietary treatments with three replicates in each treatment and 10 chicks in each pen with the dimensions of $1 \times 1.2 \mathrm{x}$ $0.8 \mathrm{~m}^{3}$. All chicks were kept in the floor pens equipped 
with hanging feeder, drinker, and rice husk as litter. Feed and water were offered ad libitum. During 10 days, all chicks got into the brooding phase with controlled room temperature of $26-35{ }^{\circ} \mathrm{C}$ and humidity of about $65-75 \%$. The mushroom crude extract was diluted with distilled water in a ratio of $1: 2$, then sprayed on basal diets.

The experiment was performed for 35 days. The basal diet was formulated for the starter (1-21 days) and the finisher phase (22-35 days). Ingredients and chemical composition of starter and finisher diets are presented in Table 1. The treatment groups included basal diet without mushroom extract as the control group (T0), basal diet with $0.2 \%$ of zinc bacitracin as AGP-treated group (T1), and basal diet containing $0.4 \%, 0.8 \%$, and $1.2 \%$ of Agaricus bisporus crude extract formed groups T2, T3, and T4, respectively. Furthermore, basal diet with $0.4 \%$, $0.8 \%$, and $1.2 \%$ of Auricularia auricular crude extract defined groups T5, T6, and T7, respectively. Feed was prepared every day and given twice a day in the morning and afternoon.

Table 1. Ingredients and chemical composition of basal diets $^{\mathrm{a}}$

\begin{tabular}{|c|c|c|}
\hline Ingredients (\%) & Starter diet & Finisher diet \\
\hline Yellow corn & 55.16 & 49.75 \\
\hline Soybean meal & 23.34 & 23.25 \\
\hline Rice bran & 0.00 & 5.00 \\
\hline Fish meal & 10.00 & 10.00 \\
\hline Meat bone meal & 5.00 & 5.00 \\
\hline Palm kernel meal & 3.00 & 3.00 \\
\hline Salt & 0.25 & 0.25 \\
\hline DL-Methionine & 0.25 & 0.25 \\
\hline Palm oil & 2.07 & 2.93 \\
\hline Premix $^{c}$ & 0.93 & 0.57 \\
\hline \multicolumn{3}{|l|}{ Chemical composition } \\
\hline Dry matter $(\%)$ & 86.58 & 86.49 \\
\hline Crude Protein $(\%)^{\mathrm{b}}$ & 23.09 & 20.93 \\
\hline Ether extract $(\%)^{\mathrm{b}}$ & 6.07 & 5.25 \\
\hline Crude fiber $(\%)^{\mathrm{b}}$ & 3.55 & 5.25 \\
\hline $\operatorname{Ash}(\%)^{\mathrm{b}}$ & 6.14 & 4.92 \\
\hline \multicolumn{3}{|c|}{ 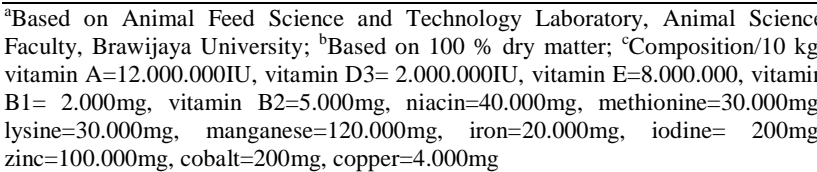 } \\
\hline
\end{tabular}

The broilers were individually weighed weekly and body weight gain (BWG) was determined. The feed intake was weekly calculated as the difference between feed offered to broiler and remaining feed. The FCR was determined by feed intake divided by BWG of the broiler during the experiment. Mortalities were recorded per pen from the beginning until the end of the experiment. The broiler production index was calculated as follows:

Production index $(\mathrm{PI})=\frac{100-\text { mortality }(96) \times \text { BWG }(\mathrm{kg})}{\text { FCR } \times \text { days of rearing }} \times 100$

\section{Statistical analysis}

Collected data in experiment 1 were analyzed descriptively while the collected data in experiment 2 were analyzed using one-way ANOVA. P-value less than 0.05 was considered statistically significant. The means of treatments were compared by Duncan multiple range test and additional orthogonal contrast test significance were considered up to $10 \%(0.10)$ in the $\mathrm{F}$ test in function of specificity and singularity comparisons. All data were tabulated and analyzed using Minitab ${ }^{\circledR} 18.1$ (Minitab Inc., USA).

\section{RESULTS}

\section{Reducing sugars, antioxidant $\mathrm{IC}_{50}$, and antimicrobial activity}

The concentration of reducing sugars and $\mathrm{IC}_{50}$ values for the antioxidant activity of Agaricus bisporus and Auricularia auricular crude extracts are shown in Table 2. Crude extracts prepared using methanol solvent had higher level of reducing sugar in comparison with other solvents. Mushrooms extracts prepared using ethanol showed the lowest antioxidant activity compared to other solvents.

Table 2. The effects of mushrooms crude extracts prepared by using different solvents on reducing sugar and antioxidant $\mathrm{IC}_{50}$

\begin{tabular}{llcc}
\hline $\begin{array}{l}\text { Mushroom } \\
\text { Species }\end{array}$ & Solvents & $\begin{array}{c}\text { Reducing } \\
\text { Sugars (\%) }\end{array}$ & $\begin{array}{c}\text { Antioxidant } \\
\mathbf{I C}_{\mathbf{5 0}}(\mathbf{m g} / \mathbf{m L})\end{array}$ \\
\hline \multirow{2}{*}{ Agaricus } & Water & 0.020 & 100.7 \\
bisporus & Ethanol & 0.016 & 112.5 \\
& Methanol & 0.075 & 96.6 \\
\hline \multirow{2}{*}{ Auricularia } & Water & 0.011 & 81.8 \\
auricular & Ethanol & 0.014 & 102.0 \\
& Methanol & 0.024 & 88.7 \\
\hline
\end{tabular}

The results of the antimicrobial sensitivity test are shown in Table 3. Agaricus bisporus extract prepared using methanol solvent showed a wider clear zone against Salmonella $(0.75 \mathrm{~mm})$, Escherichia coli $(0.73 \mathrm{~mm})$, and lactic acid bacteria $(0.62 \mathrm{~mm})$ compared to water or ethanol solvent. Auricularia auricular extract using ethanol showed a wider clear zone against Salmonella $(0.63 \mathrm{~mm})$ while Auricularia auricular extracts using methanol solvent showed a wider inhibition zone against Escherichia coli $(0.82 \mathrm{~mm})$ and lactic acid bacteria $(0.71$ 
$\mathrm{mm})$. Therefore, the methanolic extracts of Agaricus bisporus and Auricularia auricula were more effective to inhibit the growth of pathogenic bacteria.

Table 3. The effects of mushrooms crude extracts prepared by using different solvents on bacteria inhibition zone (mm)

\begin{tabular}{llccc}
\hline $\begin{array}{l}\text { Mushroom } \\
\text { species }\end{array}$ & Solvents & Salmonella & $\begin{array}{c}\text { E. } \\
\text { coli }\end{array}$ & $\begin{array}{c}\text { Lactic } \\
\text { acid } \\
\text { bacteria }\end{array}$ \\
\hline Agaricus & Water & 0.49 & 0.45 & 0.46 \\
bisporus & Ethanol & 0.46 & 0.42 & 0.52 \\
& Methanol & 0.75 & 0.73 & 0.62 \\
\hline \multirow{2}{*}{ auricularia } & Water & 0.52 & 0.56 & 0.55 \\
& Ethanol & 0.63 & 0.61 & 0.58 \\
& Methanol & 0.52 & 0.82 & 0.71 \\
\hline
\end{tabular}

\section{Growth performance}

Based on the analysis of variance, there were no significant differences among treatments in terms of broiler performance ( $p>0.05$, Table 4$)$. The control group showed a better production index than the AGP-treated group (369.8 versus 358.3). Both mushroom crude extracts could be replaced with zinc bacitracin in broiler diets. Based on the obtained results of contrast orthogonal test (Table 5), the addition of Agaricus bisporus and Auricularia auricula crude extracts in broiler diets showed no significant differences with regard to feed intake, BWG, FCR, and production index of broilers $(\mathrm{p}>0.05)$. The comparison of T6 with T7 showed that $0.8 \%$ Auricularia auricula crude extract could reduce feed intake ( $\mathrm{p}=0.086,3403$ versus $3491 \mathrm{~g} /$ chick $)$ and FCR ( $\mathrm{p}=$ $0.018,1.59$ versus 1.66). However, $1.2 \%$ Auricularia auricula crude extract showed the side effect of $\beta$-glucan contained in both edible mushroom crude extracts on broiler performance by increasing feed intake and FCR as well as reducing BWG and production index of broilers. The comparison of T3 with $\mathrm{T} 4$ showed that $0.8 \%$ of Agaricus bisporus crude extract addition could significantly reduce FCR with increasing BWG and similar feed intake $(\mathrm{p}=0.047)$.

Meanwhile, $0.8 \%$ of Agaricus bisporus crude extract significantly increased the production index while comparing T3 with $\mathrm{T} 4(\mathrm{p}=0.046)$. The addition of Agaricus bisporus and Auricularia auricular crude extracts up to $1.2 \%$ showed the side effects of $\beta$-glucan that contained in both edible mushroom species. Agaricus bisporus and Auricularia auricular crude extracts at $0.8 \%$ could lead to better broiler performance, compared to those in the control and AGP-treated group.

\section{DISCUSSION}

\section{Antioxidant $\mathbf{I C}_{\mathbf{5 0}}$ and antimicrobial activity}

Major polysaccharide in Agaricus bisporus and Auricularia auricular is $\beta$-glucan, a pathogenic associated molecular pattern (PAMP), which can stimulate and improve activity and maturity of macrophages and dendritic cells (Muta, 2006). In addition, it is reported that $\beta$-glucan could inhibit pathogenic bacteria development (Lee et al., 2020). The current study showed that Agaricus bisporus and Auricularia auricular crude extracts could inhibit the growth of pathogenic and non-pathogenic bacteria. Farzaneh et al. (2018) reported hydrolyzed Agaricus bisporus and Terfezia claveryi effectively inhibited pathogenic bacteria development. While nonblanched Agaricus bisporus inhibited Bacillus cereus, Escherichia coli, and Listeria monocytogenes. Cai et al. (2015) reported that the ethanolic extract of Auricularia auricula had effective antimicrobial activity on Staphylococcus aureus and Escherichia coli with no antimicrobial activity against Bacillus subtilis. $\beta$-glucan contained in both mushroom crude extracts could improve antimicrobial activity through enhancing bacteriocins secretion by lactic acid bacteria (Perez et al., 2014). Bacteriocins are natural antimicrobial agents against pathogenic bacteria metabolism (Santos et al., 2017).

Wang et al. (2002) reported that microwave heating with high pressure could improve the dispersion of $\beta$ glucan in water without polymers degradation. The findings of a study conducted by Zeng et al. (2012) indicated that Auricularia auricular extraction using microwave improved antioxidant activity against 2,2azinobis-3-ethylbenzthiazoline-6-sulfonate, 1,1-diphenyl2-picryl hydrazyl radical (DPPH), superoxide, and hydroxyl radical. Öztürk et al. (2011) found that methanolic extract of Agaricus bisporus had lower $\mathrm{Fe}^{3+}$ compounds $(59.87 \mathrm{mg} / \mathrm{kg})$ than hexane solvent $(206.20$ $\mathrm{mg} / \mathrm{kg})$. The ferric ion $\left(\mathrm{Fe}^{3+}\right)$ is used as an indicator of antioxidant activity in the samples, which is characterized by the reduction of $\mathrm{Fe}^{3+}$ to $\mathrm{Fe}^{2+}$ (Kozarski et al., 2011).

\section{Growth performance}

The $\beta$-glucan content of both edible mushroom species has differences in terms of $\beta$ - and $\alpha$-chain. Auricularia auricula contains a $\beta$ - chain higher than Agaricus bisporus (Lee and Kim, 2005). Supplementation of purified $\beta$-glucan $0.04 \%$ could improve the nutrient digestibility of weanling pig and affect the average daily BWG (Hahn et al., 2006). Giannenas et al. (2010) reported that $2 \%$ Agaricus bisporus in broiler diets could 
significantly improve broiler performance parameters, including BWG and FCR. It was also indicated that the water-soluble polysaccharide of Agaricus bisporus could enhance broiler performance. Another study on $\beta$-glucan supplementation in broiler diets showed no significant differences among treatments with $\beta$-glucan, Bacillus subtilis, or combination of $\beta$-glucan plus Bacillus subtilis on broiler performance (Zhang et al., 2012). Giannenas et al. (2010) found that the addition of Agaricus bisporus to broiler diets at $20 \mathrm{~g} / \mathrm{kg}$ diet increased the colonization of Lactobacilli spp. in ileum and caecum. Whereas, Agaricus bisporus did not affect small intestine development (Giannenas et al., 2010). In this regard, gut development could affect host performance, health, and nutrient absorption. In the previous study performed by Giannenas et al. (2011), it was reported that the inclusion of Agaricus bisporus on turkey diets significantly improved the villus height of the small intestine, also reduced the FCR. Phenolic compounds contained in Agaricus bisporus was $402 \mathrm{mg} \mathrm{GAE} / 100 \mathrm{~g}$ of dry weight (Keles et al., 2011) while Auricularia auricula contained phenolic compound in 3.76 $\mathrm{mg} / 100 \mathrm{~g}$ dry weight (Sikram et al. 2016). The methanolic extract of Agaricus bisporus contained phenolic content at about $85.45 \mu \mathrm{g} \mathrm{PE} / \mathrm{mg}$ extract (Öztürk et al., 2011), and Auricularia auricular water extract contained higher phenolic compounds (2.90 mg GAE/g dry matter) than ethanol or diethyl ether solvent (Boonsong et al., 2016). Polyphenol dietary treatments could enhance barrier function of small intestine by gut microbiota breakdown complex polyphenols into short-chain fatty acids. However, short-chain fatty acids could improve the recovery rate of epithelial cells leading to tight junction protein assembly in epithelium and increased intestinal permeability (Zhu, 2018). Increased intestinal permeability could affect intestinal morphometric (villus and crypt) and improve nutrient utilization and absorption resulting in the improvement of immunity status and body weight of broiler (Yamauchi, 2002). Broiler mortality correlates with the innate immunity of broiler. Intestinal mucosa not only functions in nutrient absorption but also prevents pathogenic bacteria invasion. On the other hand, goblet cells in intestinal mucosa produce mucus to bind and eliminate pathogenic bacteria and could prevent physical and chemical injuries to the intestinal mucosa. Immunoglobulin A ( $\operatorname{Ig} \mathrm{A})$ secretion in intestinal mucosa was to maintain intestinal mucosa stable and also protect it against pathogenic bacteria. Zhang et al. (2008) reported $50 \mathrm{ppm} \quad \beta-(1,3) \quad(1,6)$-glucan from Saccharomyces cerevisiae in broiler diets significantly increased secretory $\operatorname{IgA}$ and $\operatorname{IgG}$ in broilers blood serum.

Table 4. The effects of Agaricus bisporus and Auricularia auricula crude extracts on the growth performance of broiler chickens at 35 days of age ${ }^{\mathrm{a}}$

\begin{tabular}{lcccc}
\hline Treatments $^{\mathbf{b}}$ & FI $^{\mathbf{c}}$ (g/chick) & BWG $^{\mathbf{c}}(\mathbf{g} / \mathbf{c h i c k})$ & FCR $^{\mathbf{c}}$ & PI $^{\mathbf{c}}$ \\
\hline T0 & $3517 \pm 62.5$ & $2133 \pm 45.9$ & $1.65 \pm 0.04$ & $369.8 \pm 15.8$ \\
T1 & $3483 \pm 30.0$ & $2126 \pm 4.0$ & $1.64 \pm 0.01$ & $358.3 \pm 21.5$ \\
T2 & $3433 \pm 68.0$ & $2117 \pm 46.9$ & $1.62 \pm 0.02$ & $348.1 \pm 21.1$ \\
T3 & $3498 \pm 22.1$ & $2178 \pm 38.5$ & $1.61 \pm 0.03$ & $387.7 \pm 15.2$ \\
T4 & $3451 \pm 30.2$ & $2070 \pm 26.7$ & $1.67 \pm 0.01$ & $342.6 \pm 14.8$ \\
T5 & $3476 \pm 18.0$ & $2126 \pm 54.7$ & $1.64 \pm 0.04$ & $371.5 \pm 17.6$ \\
T6 & $3403 \pm 128.8$ & $2144 \pm 131.5$ & $1.59 \pm 0.05$ & $374.4 \pm 52.4$ \\
T7 & $3491 \pm 33.2$ & $2101 \pm 91.6$ & $1.66 \pm 0.06$ & $361.6 \pm 28.2$ \\
\hline
\end{tabular}

${ }^{\text {adata }}$ are expressed as mean \pm standard deviation. ${ }^{b}$ T0: control group, T1: Zinc bacitracin group, T2: Agaricus bisporus crude extract (0.4\%), T3: Agaricus bisporus crude extract (0.8\%), T4: Agaricus bisporus crude extract (1.2\%), T5: Auricularia auricular crude extract (0.4\%), T6: Auricularia auricular crude extract (0.8\%), T7: Auricularia auricular crude extract (1.2\%). ${ }^{\circ}$ FI: Feed Intake, BWG: Body Weight Gain, FCR: Feed conversion ratio, PI: Production Index of broiler

Table 5. Orthogonal contrast between the performance of treated broiler chickens with crude extracts of edible mushroom species of Agaricus bisporus and Auricularia auricula ${ }^{\mathrm{a}}$

\begin{tabular}{lcccc}
\hline Set contrast & $\mathbf{F I}^{\mathbf{c}}$ & $\mathbf{B W G}^{\mathbf{c}}$ & $\mathbf{F C R}^{\mathbf{c}}$ & $\mathbf{P I}^{\mathbf{c}}$ \\
\hline T0 versus T1-T7 & 0.153 & 0.812 & 0.433 & 0.700 \\
T1 versus T2-T7 & 0.525 & 0.944 & 0.723 & 0.715 \\
T2-T4 versus T5-T7 & 0.891 & 0.954 & 0.887 & 0.440 \\
T2 versus T3-T4 & 0.341 & 0.885 & 0.557 & 0.365 \\
T3 versus T4 & 0.349 & 0.057 & 0.047 & 0.046 \\
T5 versus T6-T7 & 0.496 & 0.950 & 0.692 & 0.854 \\
T6 versus T7 & 0.086 & 0.435 & 0.018 & 0.553 \\
\hline
\end{tabular}

${ }^{a} P$-value of orthogonal contrast test. FI: Feed Intake, BWG: Body Weight Gain, FCR: Feed conversion ratio, PI: Production Index of broiler 


\section{CONCLUSION}

The methanolic extracts of Agaricus bisporus and Auricularia auricular had higher concentrations of reducing sugar and also showed a higher capacity to inhibit the growth of pathogenic bacteria and lactic acid bacteria. In addition, $0.8 \%$ inclusion level of both mushroom species crude extracts in broiler diets showed the optimum level of broiler performance. Agaricus bisporus and Auricularia auricular crude extracts could replace antibiotic growth promoters on the broiler diet.

\section{DECLARATIONS}

\section{Authors' contributions}

Reynaldy H. Ardyansyah worked on the field trial, formulation, data collection, statistical analysis, and writing. Muhammad Halim Natsir created the idea, and designed the study. Osfar Sjofjan performed experiment 1. Danung Nur Adli revised the manuscript grammatically.

\section{Competing interests}

The authors have declared no competing interest.

\section{REFERENCES}

Afriza R and Ismanilda I (2019). Analysis of reducing sugar differences by using Lane Eynon and Luff Schoorl method in Hylocereus polyrhizus. Journal of Laboratory Management and Technology, 2(2): 90-96. DOI: https://doi.org/10.25077/temapela.2.2.90-96.2019

Boonsong S, Klaypradit W and Walaipun P (2016). Antioxidant activities of extracts from five edible mushrooms using different extractants, Agriculture and Natural Resources, 50: 89-97. DOI: http://dx.doi.org/10.1016/j.anres.2015.07.002

Cai M, Lin Y, Lou Y, Liang H, and Sun P (2015). Extraction, Antimicrobial, and antioxidant activities of crude polysaccharides from the wood ear medicinal mushroom Auricularia auricula-judae (higher Basidiomycetes). International Journal of Medicinal $\begin{array}{llll}\text { Mushrooms, } & \text { 17(6): } & \text { 591-600. }\end{array}$ http://dx.doi.org/10.1615/IntJMedMushrooms.v17.i6.90

Chae BJ, Lohakare JD, Moon WK Lee SL, Park YH, and Hahn TW (2006). Effects of supplementation of b-glucan on the growth performance and immunity in broilers. Research in Veterinary Science, $\quad 80$ : 291-298. DOI: http://dx.doi.org/10.1016/j.rvsc.2005.07.008

Farzaneh P, Khanahamadi M, Ehsani MR, and Sharifan A (2018). Bioactive properties of Agaricus bisporus and Terfezia claveryi proteins hydrolyzed by gastrointestinal proteases. Food Science and Technology, 91: 322-329. DOI: https://doi.org/10.1016/j.lwt.2018.01.044

Giannenas I, Tontis D, Tsalie E, Chronis EF, Doukas D, and Kyriazakis I (2010). Influence of dietary mushroom Agaricus bisporus on intestinal morphology and microflora composition in broiler chickens. Research in Veterinary Science, 89: 78-84. DOI: http://dx.doi.org/10.1016/j.rvsc.2010.02.003

Giannenas I, Pappas IS, Mavridis S, Kontopidis G, Skoufos J, and Kyriazakis I (2010). Performance and antioxidant status of broiler chickens supplemented with dried mushrooms (Agaricus bisporus) in their diet. Poultry Science, 89: 303-311. DOI: http://dx.doi.org/10.3382/ps.2009-00207

Giannenas I, Tsalie E, Chronis EF, Mavridis S, Tontis D, and Kyriazakis I (2011). Consumption of Agaricus bisporus mushroom affects the performance, intestinal microbiota composition and morphology, and antioxidant status of turkey poults. Animal Feed Science and Technology, 165: 218-229. DOI http://dx.doi.org/10.1016/j.anifeedsci.2011.03.002

Hahn TW, Lohakare JD, Lee SL, Moon WK, and Chae BJ (2006). Effects of supplementation of $\beta$-glucans on growth performance, nutrient digestibility, and immunity in weanling pigs. Journal of Animal Science, 84: 1422-1428. DOI: https://doi.org/10.2527/2006.8461422x

Lee JM, Jang WJ, Lee EW, and Kong IS (2020). $\beta$-glucooligosaccharides derived from barley $\beta$-glucan promote growth of lactic acid bacteria and enhance nisin $\mathrm{Z}$ secretion by Lactococcus lactis. Food Science and Technology, 122: $1-8 . \quad$ DOI: https://doi.org/10.1016/j.lwt.2020.109014

Keles A, Koca I, and Genccelep H (2011). Antioxidant properties of wild edible mushroom. Journal of Food and Processing Technology, 2(6): 2-6. DOI: http://dx.doi.org/10.4172/2157- 7110.1000130

Kozarski M, Klaus A, Niksic M, Jakovljevic D, Helsper JPFG, and Griensven LJLDV (2011). Antioxidative and immunomodulating activities of polysaccharide extracts of the medicinal mushrooms Agaricus bisporus, Agaricus brasiliensis, Ganoderma lucidum and Phellinus linteus. Food Chemistry, 129: 1667-1675. DOI: http://dx.doi.org/10.1016/j.foodchem.201211.06.029

Lee YT, and Kim YS (2005). Water-solubility of $\beta$-glucans in various edible mushrooms. Journal of Food Science and Nutrition, 10: 294 297. Available at: PDF

Minato KI, and Abe C (2013). Immunomodulating effect of polysaccharide. Chapter 17, pp. 241-250. DOI: http://dx.doi.org/10.1016/B978-0-12-397156-2.00016-8

Muta T (2006). Molecular basis for invertebrate innate immune recognition of (1-3)- $\beta$-d-glucan as a pathogen-associated molecular pattern. Current Pharmaceutical Design, 12 (32): 4155-4161. DOI: https://doi.org/10.2174/138161206778743529

Nguyen TL, Wang D, Hu Y, Fan Y, Wang J, Abula S, Guo L, Zhang J, Khakame SK and Dang BK (2012). Immuno-enhancing activity of sulfated Auricularia auricula polysaccharides. Carbohydrate Polymers, 89: 1117-1122. DOI: http://dx.doi.org/10.1016/j.carbpol.2012.03.082

Osawa T, and Namiki M (1981). A novel type of antioxidant isolated from leaf wax of eucalyptus leaves. Agricultural and Biological Chemistry, $\quad 45(3)$ : 735-739. https://doi.org/10.1080/00021369.1981.10864583

Öztürk M, Duru ME, Kivrak S, Mercan-Doğan N, Türkoglu A, and Özler MA (2011). In vitro antioxidant, anticholinesterase and antimicrobial activity studies on three Agaricus species with fatty acid compositions and iron contents: A comparative study on the three most edible mushrooms. Food and Chemical Toxicology, 49(6): 1353-1360. DOI: http://dx.doi.org/10.1016/j.fct.2011.03.019

Perez RH, Zendo T, and Sonomoto K (2014) Novel bacteriocins from lactic acid bacteria (LAB): various structures and application, Microbial Cell Factories, 13: 1-13. DOI: http://dx.doi.org/10.1186/1475-2859-13-S1-S3

Purwanto H, Hartati I, and Kurniasari L (2010). Microwave assisted extractor (MAE) improvement on ginger oil production with high zingiberene content. Momentum, 6 (2): 9-16. Available at: https://publikasiilmiah.unwahas.ac.id/index.php/MOMENTUM/arti cle/view/114/109

Santos VL, Drummond RMN, and Diaz-Souza MV (2017). Bacteriocins as antimicrobial and antibiofilm agents. Chapter 16, pp. 403-436. DOI: http://dx.doi.org/10.1016/B978-0-444-63660-7.00016-4 
Sarmah AK, Meyer MT, and Boxal ABA (2006). A global perspective on the use, sales, exposure pathways, occurrence, fate and effects of veterinary antibiotics (VAs) in the environment. Chemosphere, 65: 725-759. DOI: http://dx.doi.org/10.1016/j.chemosphere.2006.03.026

Sikram A and Supapvanich S (2016). Proximate compositions and bioactive compounds of edible wild and cultivated mushrooms from Northeast Thailand. Agriculture and Natural Resources, 50: 432-436. DOI: http://dx.doi.org/10.1016/j.anres.2016.08.001

Suresh G, Das RK, Brar SK, Rouissi T, Ramirez AA, Chorfi Y, and Godbout S (2017). Alternatives to antibiotics in poultry feed: molecular perspectives. Critical Review in Microbiology, 44, (3): 318-335. DOI: $\underline{\text { http://dx.doi.org/10.1080/1040841X.2017.1373062 }}$

Wang Q, Wood PJ, and Cui W (2002). Microwave assisted dissolution of $\beta$-glucan in water-implications for the characterisation of this polymer. Carbohydrate Polymers, 47: 35-38. DOI: http://dx.doi.org/10.1016/s0144-8617(00)00340-4

Willis WL, Wall DC, Iskhuemhen OS, Jackson JN, Ibrahim SA, Hurley SL, and Anike F (2013). Effect of level and type of mushroom on performance, blood parameters and natural coccidiosis infection in floor-reared broilers. The Open Mycology Journal, 7: 1-6. Available at: $\underline{\text { PDF }}$

Willis WL, King K, Iskhuemhen OS, and Ibrahim SA (2009). Administration of mushroom extract to broiler chickens for bifidobacteria enhancement and Salmonella reduction. Journal of $\begin{array}{llll}\text { Applied Poultry } & \text { Research, } & \text { 18:658-664. } & \text { DOI: } \\ \text { http://dx.doi.org/10.3382/japr.2008-00101 } & \end{array}$

Yamauchi K (2002). Review on chicken intestinal villus histological alterations related with intestinal function. Journal of Poultry Science, 39: 229-242. DOI: https://doi.org/10.2141/jpsa.39.229

Zeng WC, Zhang Z, Gao H, Jia LR and Chen WY (2012). Characterization of antioxidant polysaccharides from Auricularia auricula using microwave-assisted extraction. Carbohydrate $\begin{array}{llll}\text { Polymers, } & 89: & 694-700 . & \text { DOI: }\end{array}$ http://dx.doi.org/10.1016/j.carbpol.2012.03.078

Zhang ZF, Zhou TX, Ao X and Kim IH (2012). Effects of $\beta$-glucan and Bacillus subtilis on growth performance, blood profiles, relative organ weight and meat quality in broilers fed maize-soybean meal based diets. Livestock Science, 150: 419-424. DOI: http://dx.doi.org/10.1016/j.livsci.2012.10.003

Zhang B, Guo Y, and Wang Z (2008). The modulating effect of $\beta$ 1,3/1,6-glucan supplementation in the diet on performance and immunological responses of broiler chickens. Asian-Australasian Journal of Animal Science, 21, (2): 237-244. DOI: https://doi.org/10.5713/ajas.2008.70207

Zhu MJ (2018). Dietary Polyphenols, Gut Microbiota, and Intestinal Epithelial Health. Chapter 24. Washington State University, Pullman, WA, United States, DOI: https://doi.org/10.1016/B978-012-812019-4.00024-6 